\title{
MANAGING GREEN ARCHITECTURE THROUGH LIFE STYLE
}

\author{
Titien Saraswati
}

Department of Architecture, Duta Wacana Christian University, Yogyakarta, Indonesia.

e-mail: titiens@ukdw.ac.id

\begin{abstract}
Anywhere in the world, whether in rural or urban area, we cannot avoid the issue of global warming. In the urban area, about $80 \%$ of our activities are inside the buildings: in the houses, schools, offices, manufacture buildings, hotels, etcetera. Only a few of our activities take place outside the buildings. The conditions inside the buildings for our activities are far from comfort right now. In other words: our activities inside the buildings need some devices to help us to support the activities running well. In fact, some devices to support our activities generally exploit our natural resources and energies that in turn, degrade our environment.

There are also some statements that the efforts to fight degrading environment are the domain of the government only. In fact, the efforts to fight degrading environment are our business, the responsibility of all people. "Green" now is the popular word for us, and the new trend for our daily living. Whereas, this is not a new trending topic in our life, but this must be the change in our life style. That is, the need for architectural design, specifically architectural engineering that green enough for the condition of the earth, the changing climate, and degrading environment; need the changing life style.

The objective of this paper is to explore the possible things to manage green architecture through green life style. The methods used by examining life style that contributes to green architecture. The conclusion is that some simple life styles can have influencing factors to green architecture.
\end{abstract}

Keywords: energy, green architectural engineering, life style.

\section{ABSTRAK}

Di mana saja di dunia, baik di daerah pedesaan atau perkotaan, kita tidak bisa menghindari isu pemanasan global. Di daerah perkotaan, sekitar $80 \%$ aktivitas kami berada di dalam bangunan: di rumah-rumah, sekolah, kantor, bangunan manufaktur, hotel, dan sebagainya. Hanya beberapa aktivitas yang berlangsung di luar bangunan. Kondisi di dalam bangunan untuk aktivitas kami saat ini jauh dari kenyamanan. Dengan kata lain: kami membutuhkan beberapa perangkat untuk 
membantu mendukung aktivitas kami dalam bangunan agar berjalan dengan baik. Pada kenyataannya, beberapa perangkat untuk mendukung aktivitas kami umumnya mengeksploitasi sumber daya alam dan energi yang pada gilirannya, merusak lingkungan kita.

Ada juga beberapa pernyataan bahwa upaya untuk melawan penurunan lingkungan adalah domain dari pemerintah saja. Padahal, upaya untuk melawan penurunan lingkungan adalah masalah kita, tanggung jawab semua orang. "Hijau" sekarang adalah kata yang populer bagi kita, dan tren baru untuk hidup sehari-hari. Padahal, ini bukan topik tren baru dalam hidup kita, tetapi ini harus menjadi perubahan dalam gaya hidup kita. Artinya, kebutuhan untuk desain arsitektur, khususnya teknik arsitektur yang cukup hijau untuk kondisi bumi, perubahan iklim, dan penurunan lingkungan; membutuhkan perubahan gaya hidup.

Tujuan dari makalah ini adalah untuk mengeksplorasi hal-hal yang mungkin untuk mengelola arsitektur hijau melalui gaya hidup hijau. Metode yang digunakan dengan memeriksa gaya hidup yang memberikan kontribusi untuk arsitektur hijau. Kesimpulannya adalah bahwa beberapa gaya hidup sederhana dapat memiliki faktor berpengaruh terhadap arsitektur hijau.

Kata kunci: energi, teknik arsitektur hijau, gaya hidup

\section{INTRODUCTION}

"Green" becomes a popular word right now, almost in all aspects of our daily life. As mentioned above, it is not the new trend in our life, but this should be the responsibility of all people in the world.

Life style can be a choice for people. But this choice, I think, should be consider properly right now, in order to save our environment and our earth. It is a matter of choice, but it is also a matter of saving the environment and the world. But, whatever the choice it can be, we have to think that our choices should contribute to fight degrading environment.

Of course this paper just explores the possible thing, simple life style that contribute to have influencing factors to green architecture. It is really more about opening up ideas and issues for identifying simple life style that contribute to have influencing factors to green architecture.

\section{THEORY / RESEARCH METHODS}

\section{Green Architecture}

What is green architecture? According to Karyono, 2010, green architecture is the impact of the concept of sustainable architecture. He also explains that green architecture minimizing using natural resources by people in accordance to make future generation to meet their needs of natural resources. Green architecture also about the 
need for minimizing negative impacts of the buildings to the environment where the people live.

Furthermore, Wines (2008) also explains that the most complex and problematic issues facing humanity over the next century that is, how to construct a human habitat in harmony with nature. This means, eco-friendly environment should be accomplished. In other words, we should save our environment, or we should fight degrading environment and save the earth.

From the two above explanations, it can be summarized that green concept, green architecture, eco-friendly environment can be meant as adopting the systems which are very economical in using water and electrical, should be using renewable energy, water conservation, good air quality, using friendly environmental and economical building materials. These kinds of thought that never be happen before as the basic requirements for modern people in architectural engineering. Whereas architectural engineering, also known as building engineering, is the application of engineering_principles and technology to building design and construction.

There are also some simple life styles that can have influencing factors to green architecture, specifically to green architectural engineering. In other words, simple life styles that contribute to minimize the energy used for architectural engineering. What kind of life style? Let me explore as in the following.

\section{RESULTS AND DISCUSSION}

Some examples of simple life styles that can have influencing factors to green architecture, as in the following.

\section{HBKB (Hari Bebas Kendaraan Bermotor)}

HBKB (Hari Bebas Kendaraan Bermotor) means a day without motor vehicles on Sunday (Kompas, 2010). This happened in Indonesia for the first time in Jakarta, and now follows by Surakarta, Yogyakarta, and any other cities in Jawa. This life style more and more gets many followers. This can cut the energy and reduce toxic gases in the city in a big amount. In turn, this can make the quality of the air in the city cleaner and healthier.

The impact to green architectural engineering will be: cleaner, healthier air in the environment. This means we can design more natural ventilation.

\section{Refrigerator}

Inside the house, according to Green Initiative Forum (Kompas, 2010), the fridge (refrigerator) which is full of food stuffs is better than that which is empty. The fridge that full of food materials can be economical in using the energy than the one which is empty. 


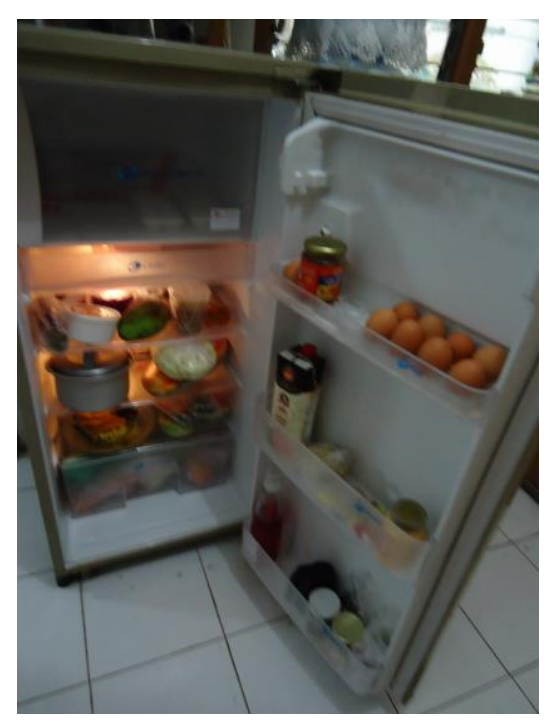

Figure 1. Do not let the refrigerator almost empty, because this will consume more electricity

Source: Author's documentation, 2013

The impact to green architectural engineering will be: economical in using the energy. This means we do not have to exploit our natural resources for the energy. We also can use renewable energy for architectural design, i. e. photovoltaic panel for electricity.

\section{Television}

Television, in this case is LCD (liquid crystal display) television, can be economical in using the energy or electricity (Kompas, 2010) compares to conventional television or tube television. Energy can be saved.
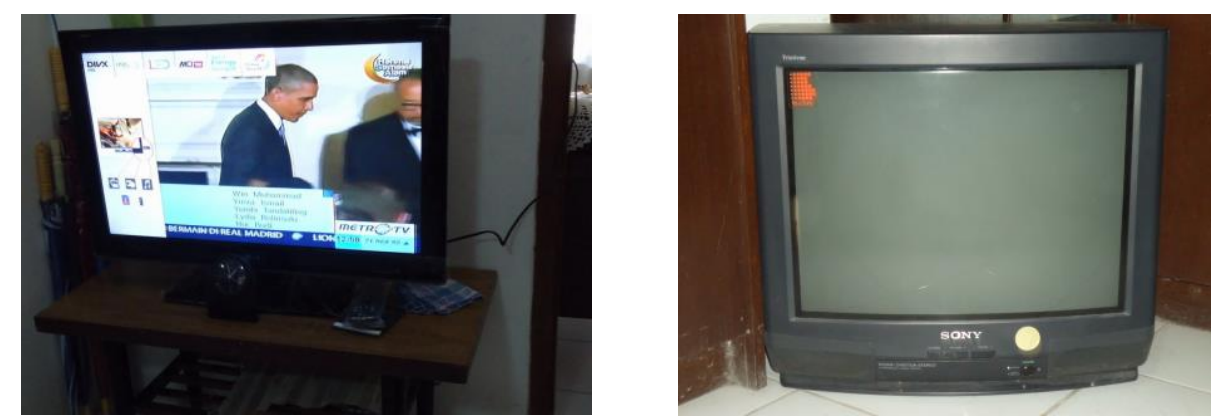

Figure 2. The LCD television (left) is better than conventional television (right) in consuming the energy.

Source: Author's documentation, 2013 
The impact to green architectural engineering will be the same as above aforementioned for the fridge, that is economical in using the energy. This means we do not have to exploit our natural resources for the energy. We also can use renewable energy for architectural design, i. e. photovoltaic panel for electricity.

\section{Earth Hour 60+}

Earth Hour 60+ was initiated by World Wide Fund for Nature, that is a movement to cut off the lights during 60 minutes or more. This third Earth Hour 60+ was happened in Indonesia for the first time on March 26, 2011 (Laksmi, 2011). The minimal act was to cut off at least two lamps inside the house in the night. More than two lamps is better! This movement has taken place in Jakarta, Bandung, Yogyakarta, Semarang, Surabaya, Malang; and up to now are followed by many other cities in Indonesia. This movement in 2010 and 2011 were claimed as the greatest environmental movement in the world. Around the world there were more than five thousands cities involved in the movement and this involving more than one billion people in the world. How great! How much more energy has been saved!

It is hoped that the above movement can be a starting point to change our life style. So that it is not only just turn the light off, but in a more big step, the aim for the future will be changing the life style and saving the earth.

The impact to green architectural engineering will be: reduces electricity, reduces the energy. This means saving the earth from exploitation of natural resources.

\section{Computer}

Laptop computer is much more better than desktop computer (Kompas, 2010). Accordingly, laptop computer can be economical in using electricity, say that a laptop computer can save about $80 \%$ in using electricity than that of desktop computer. Imagine, if an office replaces one hundred desktop computers to one hundred laptop computers, how much more electricity can be saved. So that, this also reduces using energy. Knowledge and technology make the modern people in nowadays era can live modernly and also environmentally friendly.
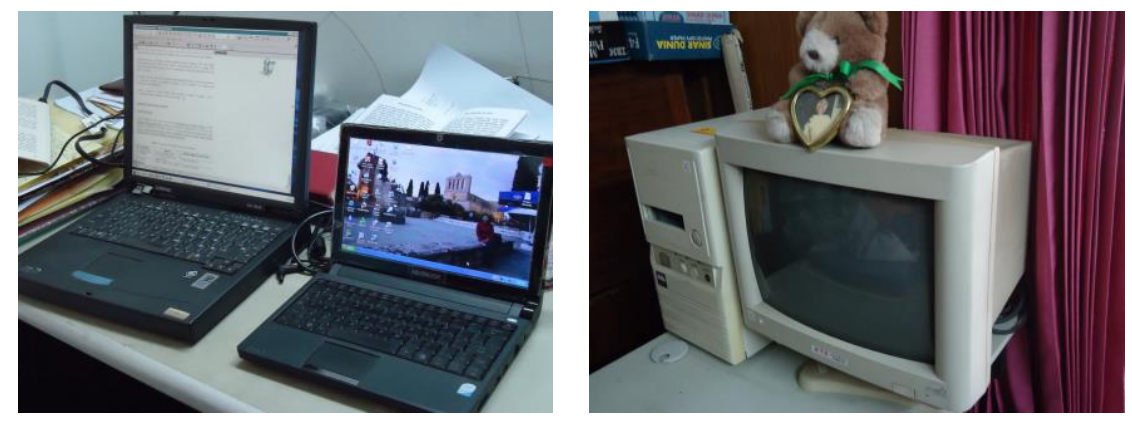

Figure 3. Laptop computers (left) much more better in saving the energy than desktop computer (right)

Source: Author's documentation, 2013 
The impact to green architectural engineering will be: reduces the energy, economical in energy. This means saving the earth from exploitation of natural resources. With the form and the size of laptop computers that handy enough to be moved, we do not have to make conventional office design as usual. We can design an office that compatible enough with our need whether we have to use the laptop or not.

\section{Plastic bags}

Reduce to use plastic bag and styrofoam material for food, because this material will be absorbed in the food, especially hot food. In turn, this will remain in our bodies and can be dangerous for our health. Also, these kinds of materials, when throw away, cannot be degraded for a long time, and can contaminate the landsoil in a long time. Better to bring our own mug or bowl when buying hot food, according to the advertisement in Kompas, 2009, from PlasticFreeBottles.com, Trent University, USA.

The impact to green architectural engineering will be: not polluting the earth, healthier for human. This means landsoil will be better. In turn, vegetation can grow up healthier, our environment will be dense with vegetation. We can design more natural ventilation. Furthermore, even though there is no direct impact to other area, but with the better landsoil make it the rainforest grows up better. The wood/timber will be abundance to support the building materials in architectural design.

\section{Renewable energy}

Not using energy from fossil, but using alternative energy such as photovoltaic panel for electricity, and windmill if possible. This will save natural resources. Also, using energy of wind, sun, and rain water. This will also affects the design of the building with more openings for natural lighting and ventilation.

The impact to green architectural engineering will be: saving natural resources. This means we can use the above renewable energy for our architectural design.

\section{Be Vegetarian}

I would like to explain the relationship between global warming, climate change, architecture, and life style in this section that concerning vegetarian life style. According to the report from Food and Agricultural Organization (FAO), United Nations (UN), entitled Livestock's Long Shadow on November 29, 2006 in its website, mentioned that about $18 \%$ contribution to global warming was came from animal farms or animal husbandry world-wide. Whereas the meaning of animal husbandry is the act or practice of cultivating crops and breeding and raising livestock. The percentage number of contribution to global warming from animal husbandry was much more bigger than that of all kinds of transportations world-wide that only $13 \%$ (Febriani, et al, 2008). From this issue of global warming then can be stated the im- 
portant thing of sustainable architecture, in which the impact of sustainable architecture is green architecture as stated by Karyono (2010) aforementioned before.

Activities in animal husbandry sector contribute 9\% CO2 carbon dioxide gas, $65 \%$ N2O nitrous oxide, and 37\% CH4 methane gas. Nitrous oxide gas N2O - resulted from the feces of animals from animal husbandry - 296 times more potential producing greenhouse effect compares to $\mathrm{CO} 2$. Whereas the greenhouse effect is a process by which thermal radiation from a planetary surface is absorbed by atmospheric greenhouse gases and is re-radiated in all directions. This illustration does not include the effect of the pollution and contamination to the earth (landsoil) and water from the feces of animal husbandry.

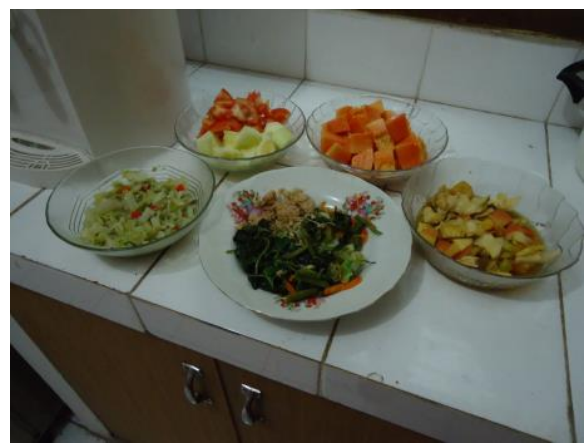

Figure 4. Vegetarian Food, No Meat Source: Author's documentation, 2013

Febrianie, et al (2008) also stated that the research by Gideon Eshel and Pamela Martin from University of Chicago came into conclusion that changing the habit from eating meat to vegetarian life style is $50 \%$ more effective to protect the earth from global warming, compares to changing SUV (sport utility vehicle) to hybride vehicle.

Furthermore, Kompas (2009) explained about human and emission, that animal husbandry contributes gas emission. These three gases from animal husbandry $(\mathrm{CO} 2, \mathrm{~N} 2 \mathrm{O}, \mathrm{CH} 4)$ contribute greatly to greenhouse effect gases. And green house effect gases is responsible for increasing the temperature of the atmosphere in the earth. Animal husbandry sector contributes $51 \%$ to greenhouses effect gases worldwide. So that, Dr Rajendra K. Pachauri, the Head of Intergovernmental Panel on Climate Change (IPCC) in Paris, in January 25, 2008 persuaded people world-wide to reduce consuming meat in accordance for minimizing global warming. That's all the above explanations about the relationship between global warming, the climate change, and vegetarian life style. It is not an easy thing to change our life style to be a vegetarian, and it is highly likely will be rejected by the people and the communities worldwide.

The impact to green architectural engineering will be: not polluting the earth and the air, reducing global warming. This means saving the earth so much! The result will be more and more amazing for architectural design, i.e. natural ventilation, natural lighting, more vegetation can be planted, availability of building materials from timber, etcetera. 
The above life styles can have a very big impact fighting degrading environment. So that it can be summarized in a table as in the following:

Table 1. The Impact of Life Style to Green Architectural Engineering

\begin{tabular}{|c|c|c|c|}
\hline No & Life Style & Impacts & Specific impact to Green Arch Eng \\
\hline 1. & $\mathrm{HBKB}$ & $\begin{array}{l}\text { cut energy, reduce toxic } \\
\text { gases in the city and the } \\
\text { environment }\end{array}$ & $\begin{array}{l}\text { cleaner, healthier air in the environ- } \\
\text { ment, more natural ventilation }\end{array}$ \\
\hline 2. & Fridge & $\begin{array}{l}\text { full fridge is better than } \\
\text { empty one, reduces the } \\
\text { energy, economical in } \\
\text { energy }\end{array}$ & $\begin{array}{l}\text { not exploit natural resources, use re- } \\
\text { newable energy for architectural design }\end{array}$ \\
\hline 3. & LCD television & $\begin{array}{l}\text { reduces energy, economi- } \\
\text { cal in energy }\end{array}$ & $\begin{array}{l}\text { not exploit natural resources, use re- } \\
\text { newable energy for architectural design }\end{array}$ \\
\hline 4. & $\begin{array}{l}\text { Laptop comput- } \\
\text { er }\end{array}$ & $\begin{array}{l}\text { reduces energy, economi- } \\
\text { cal in energy }\end{array}$ & $\begin{array}{l}\text { not exploit natural resources, office } \\
\text { design compatible enough for our need }\end{array}$ \\
\hline 5. & Earth Hour 60+ & $\begin{array}{l}\text { reduces electricity, reduc- } \\
\text { es the energy, saving the } \\
\text { earth }\end{array}$ & not exploit natural resources \\
\hline 6. & No plastic bags & $\begin{array}{l}\text { not polluting the earth, } \\
\text { healthier for the human, } \\
\text { landsoil will be better }\end{array}$ & $\begin{array}{l}\text { more vegetation, more natural ventila- } \\
\text { tion, rainforest grows up better, tim- } \\
\text { ber/wood will be abundance for build- } \\
\text { ing materials }\end{array}$ \\
\hline 7. & $\begin{array}{l}\text { Renewable } \\
\text { energy }\end{array}$ & saving natural resources & $\begin{array}{l}\text { renewable energy used in architectural } \\
\text { design }\end{array}$ \\
\hline 8. & Vegetarian & $\begin{array}{l}\text { not polluting the earth and } \\
\text { the air, reducing global } \\
\text { warming, saving the earth }\end{array}$ & $\begin{array}{l}\text { natural ventilation, natural lighting, } \\
\text { more vegetation planted, availability of } \\
\text { building materials from timber }\end{array}$ \\
\hline
\end{tabular}

\section{CONCLUSIONS}

Green architecture also stated the need for minimizing the negative impacts of the buildings to the environment in where the people live. Simply, green concept can be meant as adopting the systems which are very economical in using natural resources and the energy, good air quality, using friendly environmental economical building materials and energy. These kinds of thought that never be happen before as the basic requirements for modern people in architectural engineering.

The above life styles are simple enough in reducing the energy, means fighting degrading environment. In turn, even though it is not in a short time but in a long one, the above life styles can contribute to cleaner and healthier environment that we can design buildings with more natural ventilation and natural lighting in the days.

It is hoped that the above explanations can be a starting point to change our life style. So that it is not only just change the life style, but in a more big step, the aim for the future will be saving the earth. 


\section{ACKNOWLEDGMENT}

I would like to thank to the Head of Architecture Department, Duta Wacana Christian University, who encourages me to write my paper for this International Seminar.

\section{REFERENCES}

Febrianie, S., Soelastri, and Wresti, C. (2008), Santapan Vegan Demi Bumi Kita (Vegan Food for the sake of the Eart, Kompas, p. 14.

Green Festivals (2010), Setiap Orang Bisa Berbuat bagi Bumi (Green Festivals. Everybody Can Do for the Earth, Kompas, p. 14.

Karyono. T. H. (2010), Green Architecture, PT Raja Grafindo Perkasa, Jakarta.

Kita dan Emisi (We and the Emission) (2009), Kompas, p. 14.

Laksmi, B. I. (2011), Memadamkan Lampu Sejam dan Gaya Hidup (Cut Off the Light One Hour and Life Style). Kompas, p. 14.

Wines, J. (2008). Green Architecture. Taschen GmbH, Koln, Germany. 
Saraswati: MANAGING GREEN ARCHITECTURE THROUGH LIFE STYLE

This page intentionally left blank 